\title{
Elemental Analysis of Indian Coffee Powder Samples using Hand Held X-Ray Fluorescence Spectrometer
}

\author{
Mammen Denni ${ }^{\star}$ and Daisy Joseph ${ }^{2}$ \\ 'School of Science, Navrachana University, Vadodara, India \\ 2Nuclear Physics Division, Bhabha Atomic Research Centre, Trombay, Mumbai, India
}

\section{Article Info}

\section{*Corresponding author:}

Mammen Denni

School of Science

Navrachana University

Vasana-Bhayli Road, Vadodara

India

E-mail: drdenni.mammen@gmail.com

\section{Received: July 30, 2019 \\ Accepted: August 22, 2019 \\ Published: August 30, 2019}

Citation: Denni M, Joseph D. Elemental Analysis of Indian Coffee Powder Samples using Hand Held X-Ray Fluorescence Spectrometer. Madridge J Anal Sci Instrum. 2019; 4(1): 109-112.

doi: $10.18689 /$ mjai-1000120

Copyright: ( $\subset 2019$ The Author(s). This work is licensed under a Creative Commons Attribution 4.0 International License, which permits unrestricted use, distribution, and reproduction in any medium, provided the original work is properly cited.

Published by Madridge Publishers

\begin{abstract}
Elemental composition of ten samples of instant and roasted ground coffee powders available in markets of India have been analyzed using X-ray fluorescence technique. The samples were analyzed for thirty one elements, out of which major elements were $\mathrm{K}$ and $\mathrm{Ca}$. $\mathrm{Al}, \mathrm{Fe}, \mathrm{Ni}, \mathrm{Mg}, \mathrm{Mn}, \mathrm{Sb}, \mathrm{Sn}$ and $\mathrm{Zn}$ were observed to be present in the smaller quantities. Nonmetals such as $\mathrm{S}, \mathrm{P}$ and $\mathrm{Si}$ were detected in almost all the samples. The samples also showed presence of rare earth metals like $\mathrm{W}, \mathrm{Zr}, \mathrm{Y}, \mathrm{Ag}, \mathrm{Sr}, \mathrm{Rb}, \mathrm{Nb}$ and $\mathrm{Mo}$. Toxic metals like $\mathrm{Hg}$ and $\mathrm{As}$ were not detected in any of the samples, while traces of $\mathrm{Cd}$ and $\mathrm{Pb}$ were found to be present in four samples each. With the absence of toxic elements coffee can be considered a safe beverage. Detection of radioactive elements $\mathrm{U}$ and Th in the coffee samples is an important finding of this research work. Results of elemental analysis of the analyzed coffee samples were correlated to the soil analysis data of their geographical origins. There have been good correlations between elements reported in the soil and those detected in the coffee samples. The motive of the research work is to bring out the goodness of coffee in terms of their elemental composition and also their variation with regard to their geographical origin.
\end{abstract}

Keywords: Coffee powder; X-ray fluorescence; Trace elements; Toxic metals; Detection; Safety.

\section{Introduction}

Quality of coffee depends on number of factors such as variety, cultivation practices, processing, soil composition and climate. Content of elements depends mainly on the quality of soil and water in the coffee plantations. Elemental analysis of coffee beans has been performed by various techniques such as atomic absorption spectroscopy (AAS), neutron activation analysis (NAA) and inductively coupled plasma atomic emission spectroscopy (ICP-AES). These techniques however require time consuming and cumbersome sample preparation procedures. Elemental analysis of solid samples of coffee has been directly analyzed using Particle-Induced X-ray Emission (PIXE) technique [1]. Coffee cultivation requires use of fertilizers that can provide macronutrients and micronutrients for proper growth of the plants [2]. Organic fertilizers do not contribute to $\mathrm{Cd}$ and $\mathrm{Pb}$ content, but do contribute significantly to presence of $\mathrm{Cu}, \mathrm{Cr}, \mathrm{Mn}, \mathrm{Zn}$ and $\mathrm{Ni}$. There are significant differences between elements present in plants growing in artificially and naturally fertilized soils. Scientific evidence shows that there is a strong correlation between elements present in soil and in coffee beans $[3,4]$. Elements such as $\mathrm{Ba}, \mathrm{As}, \mathrm{Tb}, \mathrm{Gd}, \mathrm{Ce}, \mathrm{Co}, \mathrm{Cr}$, Dy, Sc, V, Eu, Hf, La, Lu, Mo, Ni, Pb, Sb, Se, Sm, Sr, Ta, Cd, Ti, $\mathrm{Tm}, \mathrm{Th}, \mathrm{U}$, and $\mathrm{Yb}$ are have not been detected in samples of roasted ground as well as instant coffee [5]. 
The analysis of coffee powders during the present research work has been carried out using X-ray Fluorescence technique. This technique is considered to be the most sensitive, multi-elemental, rapid technique which needs no sample preparation to analyze powders like coffee in the range of ppm-\% [6]. A typical spectrometer uses an X-ray tube to excite the sample with $X$-rays with sufficient energy to knock out electrons from the inner shells of the sample atoms. Electrons from outer shells then drop down into the vacant inner-shell positions, and the characteristic $X$-rays are ejected. This is known as X-ray fluorescence (XRF). In the Hand Held XRF (HHXRF), the energies of the $X$-rays emitted by the sample are measured using a Silicon Drift Detector (SDD) which has a graphene window to enable detection of low $Z$ elements such as $\mathrm{S}, \mathrm{P}$ and $\mathrm{Al}$ which is not possible in the conventional XRF which uses detector with Be window. The Be window absorbs low energy $X$-rays emitted by elements such as $\mathrm{Al}$ and below. Computer analysis of this data yields an energy spectrum which defines the elemental composition of the sample. The energy of the peak gives the element signature, and the number of X-rays counted in the peak gives the amount of the element present in the sample.

The present study brings to light the correlation between elements present in commonly consumed coffee brands available in the markets of India, and the effect of soil composition of the areas of their geographical origin. This kind of correlation in coffee samples has been reported for the first time in the country.

\section{Experimental}

Coffee samples were procured directly from various distributors in India. The selected brands of coffee were: 1) Nescafe Instant and Nescafe Sunrise manufactured by Nescafe India Limited, Mysore, India; 2) Bru Instant and Bru Green Gold manufactured by Hindustan Unilever Limited, Virudhunagar, Tamil Nadu, India; 3) Colombian Brew and Teddy Roosevelt manufactured by Snowlan Epicure Private Limited, Pune, India; 4) Continental Xtra, Continental Malgudi and Minerva Kaapi manufactured by CCL Products (India) Limited, Guntur, Andhra Pradesh, India; 5) Coffee Shopee manufactured by Uday Krishna Agro Foods, Kolar, Karnataka, India. Moisture was removed from the coffee samples by drying at $110^{\circ} \mathrm{C}$ for 3 hours in a vacuum oven. The dried samples were ground to fine powder using a mortar and pestle and stored in airtight bags till analysis. The coffee powders were analyzed using OLYMPUS VANTAS C-series hand held X-ray spectrometer (Figure 1). Each sample was placed in a cubical box and irradiated for 60 seconds by $X$-rays produced from a rhodium excitation source. Typical spectrum of the coffee powder analyzed is shown in figure 2 . The beam lines were of 12 to $36 \mathrm{KeV}$ (Beam 1) and 0-12 KeV (Beam 2).

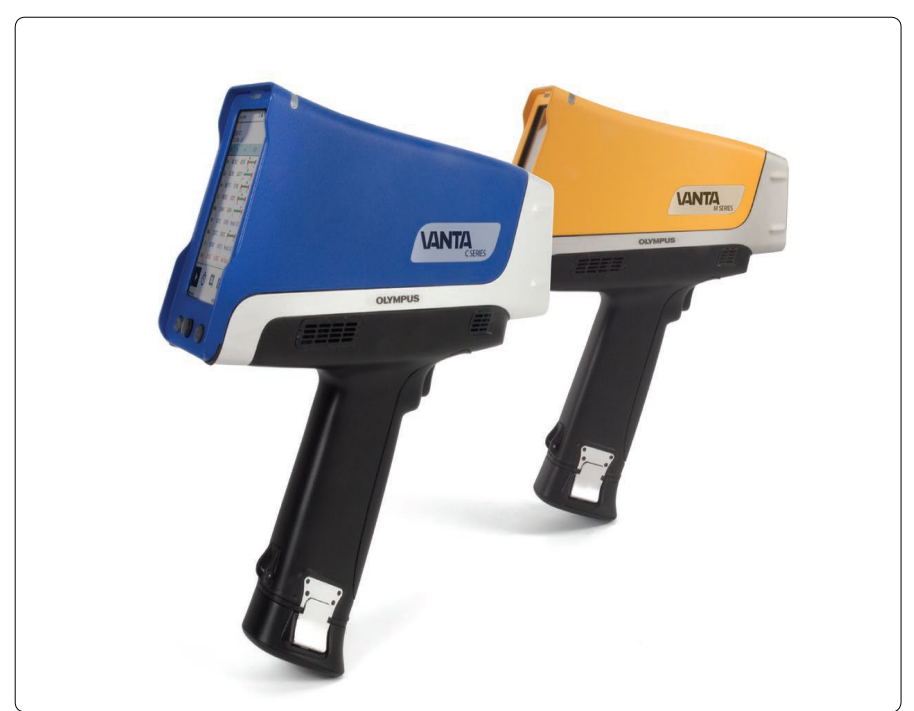

Figure 1. HHXRF used for analysis of coffee powder.

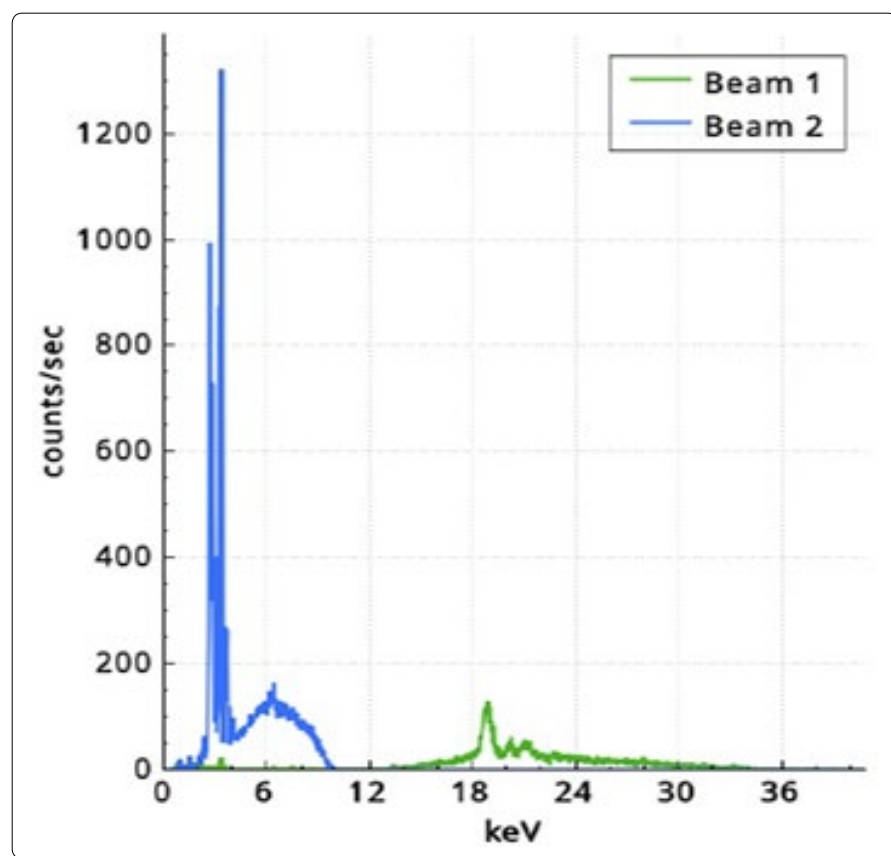

Figure 2. Typical X-ray spectrum of the analyzed coffee powder.

\section{Results and Discussion}

Table 1 shows the trace elements present in each analyzed coffee sample.

Table 1. Trace elements in coffee powders using HHXRF (in ppm).

\begin{tabular}{|l|c|c|c|c|c|c|c|c|c|c|}
\hline & Bru Instant & $\begin{array}{c}\text { Bru Green } \\
\text { Gold }\end{array}$ & $\begin{array}{c}\text { Nescafe } \\
\text { Classic }\end{array}$ & $\begin{array}{c}\text { Nescafe } \\
\text { Sunrise }\end{array}$ & Continental Xtra & $\begin{array}{c}\text { Continental } \\
\text { Malgudi }\end{array}$ & $\begin{array}{c}\text { Coffee } \\
\text { Shoppee }\end{array}$ & $\begin{array}{c}\text { Columbian Brew } \\
\text { Minerva } \\
\text { Kaapi }\end{array}$ & $\begin{array}{c}\text { Teddy } \\
\text { Roosevelt }\end{array}$ \\
\hline K & 94300 & 86900 & 36450 & 14800 & 44800 & 62900 & 69960 & 51430 & 85400 & 91800 \\
\hline Ca & 6220 & 5040 & 3810 & 9520 & 2670 & 12060 & 3020 & 5870 & 3590 & 4890 \\
\hline P & 2970 & 2230 & 640 & 3130 & 700 & 1770 & 1930 & 1360 & 1450 & 2760 \\
\hline Si & 3980 & 2340 & 1210 & 1430 & 1260 & 660 & 1010 & 850 & ND & ND \\
\hline S & 1940 & 1930 & 1180 & 2220 & 920 & 1420 & 1100 & 1870 & 1260 & 1770 \\
\hline Fe & 1329 & 1089 & 370 & 335 & 184 & 2250 & 400 & 166 & 226 & 104 \\
\hline Al & 4400 & 5100 & ND & ND & 4600 & 6900 & ND & ND & ND & ND \\
\hline Sr & 19 & 19 & 13 & 6 & 16 & 34 & 20 & 14 & 13 & 12 \\
\hline
\end{tabular}




\begin{tabular}{|c|c|c|c|c|c|c|c|c|c|c|}
\hline $\mathrm{Rb}$ & 40 & 44 & 24 & 51 & 46 & 29 & 60 & 37 & 78 & 63 \\
\hline $\mathrm{Zn}$ & ND & 29 & 28 & ND & 14 & ND & 6 & 8 & ND & 32 \\
\hline $\mathrm{Nb}$ & ND & 5 & 4 & 12 & 11 & ND & 11 & 7 & 11 & 7 \\
\hline $\mathrm{Ag}$ & ND & 31 & 37 & 93 & 48 & 38 & 57 & 31 & 49 & 43 \\
\hline$U$ & 21 & 43 & 17 & 29 & ND & 20 & ND & 6 & 16 & 11 \\
\hline Th & ND & 24 & 37 & 60 & 16 & 39 & 17 & 38 & 94 & 20 \\
\hline$Y$ & 16 & 9 & 12 & 19 & 5 & 8 & ND & 12 & 7 & 5 \\
\hline $\mathrm{Zr}$ & 23 & 18 & 17 & 22 & 3 & 62 & 14 & ND & 6 & ND \\
\hline $\mathrm{Cd}$ & ND & ND & ND & 69 & 54 & ND & ND & ND & 44 & 55 \\
\hline $\mathrm{Pb}$ & ND & $N D$ & 6 & ND & ND & 11 & 16 & 5 & ND & ND \\
\hline $\mathrm{Cu}$ & ND & $N D$ & 40 & 65 & $N D$ & ND & ND & 28 & ND & ND \\
\hline Sn & ND & ND & ND & ND & 23 & ND & ND & 48 & ND & ND \\
\hline $\mathrm{Mg}$ & ND & ND & ND & ND & 27000 & ND & ND & ND & ND & ND \\
\hline $\mathrm{Ni}$ & ND & $N D$ & 74 & ND & $N D$ & ND & ND & ND & ND & ND \\
\hline $\mathrm{Sb}$ & 94 & $N D$ & ND & ND & $N D$ & ND & ND & ND & ND & ND \\
\hline $\mathrm{Mn}$ & ND & ND & 96 & ND & ND & ND & ND & ND & ND & ND \\
\hline W & 15 & ND & ND & ND & ND & 24 & ND & ND & ND & ND \\
\hline
\end{tabular}

Significant quantities of $K$ were observed in all coffee samples. A high concentration of the $\mathrm{K}$ was observed in both samples of Bru, while both Nescafe samples showed lesser K concentrations. High $\mathrm{K}$ concentration causes soil to become alkaline, which is an important factor determining the $\mathrm{pH}$ of the soil. High concentrations of $\mathrm{Ca}$ and $\mathrm{P}$ were observed in all the analyzed coffee samples. Si and $\mathrm{S}$ were found to be high in both the Bru coffee samples. Si was however absent in Minerva Kaapi and Teddy Roosevelt samples. Fe was observed in all samples, but particularly higher in Bru and Continental Malgudi samples, which could be attributed to the red soil of their geographical origin. All the analyzed samples showed presence of $\mathrm{Sr}$ and $\mathrm{Rb}$ in traces. Among the micronutrients, $\mathrm{Zn}$ was detected in 6 samples, $\mathrm{Cu}$ in only 3 samples, while $\mathrm{Mn}$ and $\mathrm{Mg}$ were observed in only one sample each. Out of the ten samples Ag, Th, and $\mathrm{Y}$ were detected in 9 samples each. Metals like $\mathrm{Nb}, \mathrm{U}$, and $\mathrm{Zr}$ were each detected in 8 samples. Toxic metals $\mathrm{Pb}$ and $\mathrm{Cd}$ were each found present in 4 samples within permissible limits. Metals like $W$ and $S n$ occurred in just 2 samples each, while metals like $\mathrm{Sb}$ and $\mathrm{Ni}$ were the trace metals which were found in just one sample each. Toxic metals As and $\mathrm{Hg}$ were not detected in any of the analyzed samples. Elements like $\mathrm{Co}, \mathrm{Ti}, \mathrm{V}, \mathrm{Cr}, \mathrm{Se}, \mathrm{Bi}$ and Mo were found absent in all the samples.

The samples Continental Malgudi and Continental Xtra are manufactured in Guntur district of Andhra Pradesh, a state located in the southeast part of India. The soil in this district is pale red to dull yellow with high amount of $\mathrm{Ca}$ and $\mathrm{K}$, and low in $\mathrm{N}$ and $\mathrm{P}$ content. Micronutrients are present in sufficient amount, except for zinc [7]. The coffee powder of Continental Malgudi manufactured in the region shows high concentrations of $\mathrm{K}$ and $\mathrm{P}$, and absence of $\mathrm{Zn}$, in conjunction with the soil data. $\mathrm{Zn}$ was however observed in the Continental Xtra sample.

Nescafe and Coffee Shopee samples are sourced from Kolar and Mysore districts in Karnataka, which is a state situated in southwest region of India. Soil of both districts has $\mathrm{pH}$ 6.5-8.5, and contains $\mathrm{K}$ and $\mathrm{P}$, and sufficient amount of $\mathrm{Zn}$ and $\mathrm{S}$. However the soil of Kolar district shows deficiency of $\mathrm{S}$ [8]. The slightly acidic nature of the soil could be the reason for absence of Al metal in the samples, since uptake of Al is favored in alkaline soil. The slightly acidic nature of the soil could be attributed to lower $\mathrm{K}$ content in the soil of Mysore, which could be the reason of low concentration of $K$ in Nescafe samples, sourced from the region.

Samples of Bru are sourced from Virudhunagar district in Tamil Nadu, which is the southernmost state of India. Reports of soil analysis of this district indicate deficiency of micronutrients such as $\mathrm{Zn}, \mathrm{Mn}, \mathrm{Cu}$ and Fe. The $\mathrm{pH}$ of the soil varied from 7.2 to 8.8 , which is slightly alkaline [9]. Increase in alkalinity favours the uptake of $\mathrm{Al}$ metal by coffee plants. This is proved by the significant amounts of Al metal in Bru Instant and Bru Green Gold samples which are manufactured in Virudhunagar district. The district is rich in limestone [10], which justifies the high calcium contents in Bru Instant and Bru Green Gold samples.

Columbian Brew coffee and Teddy Roosevelt are manufactured in Pune district, which is located in central India. Soil of Pune district is reported to have slightly acidic to neutral $\mathrm{pH}$, with high $\mathrm{K}$ and $\mathrm{P}$ content [11]. The acidic nature of the soil could justify the absence of Al metal in both coffee samples manufactured in the region. This is also in support of the report that Al uptake is good in alkaline soil. Good amounts of $\mathrm{K}$ and $\mathrm{P}$ in both samples also are in support of the reported soil data.

Reports released by Government of India show the data of deficiency of elements in different states of the country. Deficiency of $\mathrm{Mn}$ is prevalent in soils of certain states of India such as Assam, Karnataka, Tamil Nadu, Punjab, Haryana and Gujarat [12]. This is evident by the fact that Mn was found absent in all the samples except in one sample.

States such as Karnataka, Tamil Nadu and Jharkhand have been analyzed to show deficiency of Cu metal [12]. The metal was found in very few samples.

\section{Conclusion}

The present study probes the elemental compositions present in commonly used instant and ground roasted coffee brands in India. The study reveals very few traces of toxic metals in the coffee samples, within permissible limits showing that they are safe for consumption. Correlation of elements 
detected in the coffee powders with the soil content of their geographical origins has been conducted for the first time in India. The study also establishes the fact that soil composition of the geographical origin affects the elemental accumulation in plants. X-ray fluorescence technique has emerged as a non-destructive, sensitive, and multi-elemental technique to analyze coffee powders with great ease without the need of cumbersome sample preparation procedures.

\section{Acknowledgements}

We acknowledge the services of I. R. Technology Services Pvt. Ltd., Mahape, Navi Mumbai, Maharashtra, India for the XRF analysis data of the coffee powders.

\section{References}

1. Debastiani R, dos Santos CEI, Yoneama ML, Amaral L, Dias JF. Ion beam analysis of ground coffee and roasted coffee beans. Nucl Instrum Methods Phys Res B. 2014; 318: 202-206. doi: 10.1016/j.nimb.2013.05.105

2. Pohl P, Stelmach E, Welna M, Szymczycha-Madeja A. Determination of the Elemental Composition of Coffee Using Instrumental Methods. Food Anal Methods. 2012; 6 (2): 598-613. doi:10.1007/s12161-012-9467-6

3. dos Santos JS, dos Santos MLP, Conti MM, dos Santos SN, de Oliveira E. Evaluation of some metals in Brazilian coffees cultivated during the process of conversion from conventional to organic agriculture. Food Chem. 2009; 115(4): 1405-1410. doi: 10.1016/j.foodchem.2009.01.069

4. dos Santos JS, dos Santos MLP, Conti MM. Comparative study of metal contents in Brazilian coffees cultivated by conventional and organic agriculture applying principal component analysis. J Braz Chem Soc. 2010; 21(8): 1468-1476. doi: 10.1590/S010350532010000800009
5. Anderson KA, Smith BW. Chemical profiling to differentiate geographical growing origins of coffee. J Agric Food Chem. 2002; 50(7): 2068-2075. doi: 10.1021/jf011056v

6. Masresha Feleke $H$, Srinivasulu A, Surendra K, et al. Energy Dispersive $\mathrm{X}$-Ray Fluorescence Elemental Analysis of Roasted and Non- Roasted Ethiopian Coffee Specialty. IOSR J Environ Sci Toxicol Food Technol. 2018; 12(4): 51-70. doi: 10.9790/2402-1204015170

7. Nandy T. Nutrient status of some coastal soils of Guntur district, Andhra Pradesh. Journal of the Indian Society of Coastal Agricultural Research. 2017; 35(2): 78-82.

8. Wani SP, Sahrawat KL, Sarvesh KV, Baburao Mudbi, Krishnappa K. Soil Fertility Atlas for Karnataka, India. International Crops Research Institute for the Semi-Arid Tropics. 2011. ISBN 978-92-9066-543-4

9. Shanmugasundaram R, Savithri P. Available micronutrients in soils of Virudhunagar and Vellore districts of Tamil Nadu. Agric Sci Digest. 2002; 22(4): 232-235.

10. National Agricultural Development Programme (NADP) District Agriculture Plan Coimbatore District. Centre for Agricultural and Rural Development Studies, Tamil Nadu Agricultural University, Coimbatore. 2008.

11. Government of Maharashtra. Report on SWOT Analysis of Pune district. 2017.

12. National Food Security Mission. Guidelines for use of micronutrients, soil ameliorants, and integrated nutrient management practices in NFSM states. Ministry of Agriculture, Government of India, New Delhi. 2012. 